\title{
An Overview of Nepalese Medicinal Plant Trade with China
}

\author{
Arjun Chapagain ${ }^{1 *}$, June Wang ${ }^{1}$ and Dipesh Pyakurel ${ }^{2}$ \\ ${ }^{1}$ Department of Public Policy, City University of Hong Kong, Hong Kong \\ ${ }^{2}$ Resources Himalaya Foundation, Nepal
}

Submission: March 17, 2021; Published: May 17, 2021

*Corresponding author: Arjun Chapagain, Department of Public Policy, City University of Hong Kong, Hong Kong

\begin{abstract}
Despite a thousand years of history in Nepalese medicinal plant trade to China, there has not been much comprehensive studies that overview the trade from past to present. This study explores the history of the Nepalese medicinal plant trade with China, providing a complete overview of the species involved, their conservation status, and demand drivers. Accordingly, in this study the literature on Sino-Nepal trade relations is reviewed, government reports and data tracked, and interviews conducted with forest officials and exporters trading with China. This study documents 54 medicinal plant species previously (or currently) traded with China. The value of medicinal plants traded with China is worth more than three times as much as the volume exported in percentage terms. Twenty-six species fall into national or international conservation categories. The industrialization of Tibetan medicine, access to modern transportation for the supply of medicinal ingredients and products, globalization of the medicinal plant market, and high per capita income of Chinese people have resulted in consumer behavior shifting toward herbal medication and an increase in the Nepalese medicinal plant trade with China. To mitigate the depletion of resources caused by high demand of medicinal plants, immediate action is required to address trade sustainability as well as prioritize local traditional knowledge and resource-based industry for the substantial socio-cultural and economic benefits both to the local people and nation.
\end{abstract}

Keywords: History; Industrialization; Medicinal plants; Traditional medicine; China

\section{Introduction}

Nepal and China have centuries-old social, cultural, and economic relations; the salt-grain trade through the transHimalayan silk route being an example [1,2]. Medicinal knowledge and medicinal plants formed a major part of the trans-Himalayan salt-grain trade. The medicinal plant trade from Nepal to China is currently on the rise, particularly after the industrialization of Tibetan medicine in the 1990s, and the introduction of Good Manufacturing Practice (GMP) standards for pharmaceuticals in 2001 [3]. For example, with an increase in the traditional medicine market, Tibetan medicine has grown tenfold between 2000 and 2017, producing pharmaceuticals worth 615.3 million USD in 2017, led in absolute and relative numbers by China [4]. The centuries-old Tibetan medicinal practice has flourished throughout the neighboring Himalayan regions of Bhutan, Nepal, and India among the Tibetan populations along the interwoven networks for trade, increasing the spread of Buddhism and other cultural exchanges, pilgrimage, and Tributum [5]. However, many raw materials used in Tibetan medicine are not native to Tibet, and medicinal plants imported from neighboring countries like India and Nepal constitute a considerable part of the Tibetan medicine system. For centuries, the cross-border movement of merchants and medicinal ingredients across spatial and conceptual borders has been essential to Tibetan medicine practice $[3,6]$.

Nepalese medicinal plants have been exported for centuries [7], primarily to India and China $[8,9]$. With the industrialization of traditional medicine and globalization of the medicinal plant trade, the bulk of Nepalese medicinal plants are exported to India, China, and beyond [10-13], where they are the subject of increasing interest in the herbal curative system [14]. This high demand may be due to the significant efficiency [15] of bioconstituents in modern medicine, the proximity to centuries-old systems (Ayurveda, Tibetan Medicine and Traditional Chinese Medicine) [16] or their use in the preparation of aromatic products, cosmetics, plant fibers, herbal dyes, food flavoring [17].

From 11,971 species of flowering and non-flowering plants, including fungi and lichens [18] more than 2,300 have medicinal value [19] while 300 are traded and exported from Nepal [20]. About $39 \%$ of all traded medicinal plants are formally protected by 
the Government of Nepal or included in national and international conservation categories to control over and pre-harvesting [20]. The traditions and culture of Pan-Himalayan people are related to these plants for various purposes including household activities (fencing), religious beliefs (incense), medicinal purposes, etc. According to a recent study, Nepal supplies more than 50 countries worldwide with medical plans [11], 13 of which import every year [12]. Medicinal plant processing enterprises in Nepal are also experiencing continuous growth [21].

The most recent comprehensive study of the medicinal plant trade is that by Pyakurel et al. [20], although destination countries are not mentioned. Despite the historical and modern importance of trade in medicinal plants, there is no comprehensive list of the species traded from Nepal to China. Recent studies have estimated the number of traded species at about 17 [3:107,21-23]. Here, the historical trade information is combined with the contemporary to create a comprehensive overview of species previously or currently traded [20].

The present study aims to:

(i) explore the historical events initiating the transHimalayan medicinal plant trade,

(ii) create a comprehensive overview of species previously or currently traded from Nepal to China, to analyze their conservation status and present trade share, and

(iii) reveal the major demand drivers of Nepalese medicinal plants in China.

\section{Methodology}

Literature available on online journals and proceedings, published from 1995 to 2017 relating to the first International Medical Symposium in Tibet, the establishment of Tibetan medicine, and ancient trans-Himalayan trade from Nepal to Tibet, China [1,3,5,6,25-30] were searched using keywords like Tibetan Medicine History, Himalayan Medicinal Plants, Trans-Himalayan Trade, Nepal China trade relations, and reviewed, and analyzed to explore the history of the medicinal plant trade from Nepal to Tibet, China.

A bibliography of 350 studies on medicinal plants, fungi, and lichens traded in and from Nepal compiled from 29 key resource institutions in Nepal [31] were reviewed to cover the period up to 2015. Existing literature and online journals relating to NepalChina trade relations including medicinal plants were researched and reviewed to cover the period from 2015 to 2020 . Government reports and data from Customs and Tibetan border districts were also reviewed.

To support secondary information and capture contemporary traded species, field surveys were carried out in major medicinal plant trade hubs and routes to China in 2016 (Tatopani Customs, Sindhupalchok, Tribhuvan International Airport, and exporters at Thamel, Kathmandu, number of species traded to China, $n=33$ ) [32] and in 2020 (Kimathanka-Chentang border crossing, Sankhuwasabha, $n=8$ [33] and the Divisional Forest Office, Kathmandu, $n=24$ [34]). Interviews were conducted on traded species (name, parts traded, uses, etc.) with officials and local Tibetan border exporters trading to China. The information on medicinal plants traded to China recorded from both primary and secondary sources were merged into a list, sorted, and any duplications removed. Finally, the listed species $(n=54)$ were tabulated into families, recent scientific names with author citations; their English, Nepali, Tibetan, and Chinese names; life form; parts traded; occurrence; distribution in Nepal with altitudinal variation; conservation status, and source (Appendix I) following the Catalogue of Life [35], Plants of the World online [36], IUCN [37], CAMP [38], CITES [39], and Pyakurel et al. [20].

The present trade in medicinal plants was analyzed in terms of average net weight and trade value using the Harmonized System code 1211 of UN COMTRADE DATA from 2013 to 2017. The conservation status of investigated species was verified according to national $[38,40]$ and international $[37,39]$ conservation categories. The demand drivers of Nepalese medicinal plants in China were revealed during a review of contemporary literature on the modernization of the Tibetan medicine industry $[3,4,6,25,41$ 43].

\section{Historical Events Initiating the Trans-Himalayan Medicinal Plant Trade to Tibet}

The trade in medicinal plants from Nepal to Tibet dates back to the eighth century (728 CE/AD) when Tibetan emperor Trisong Detsen (756-97) invited nine traditional doctors from neighboring regions in India, Kashmir, Tang, Persia, Drugu, East Turkestan, Mongolia, Dolpo, and Nepal to the first International Medical Symposium in Tibet [26-28]. The output of the conference played a directive role to unify the practise the traditional medicine. "The Four Medical Tantras" published during the twelfth to fourteenth century, marked the formation of Tibetan medical theory, combined with political and institutional influence which led in the establishment of unified version for the theory and practise of Buddhist medicine in Tibet $[29,30]$. This theory has since been studied in whole or part by practitioners during their medical training, serving as the manifestation of the school of Tibetan medicine [26-28,44]. Tibetan medicine consists of medical compounds derived from various medicinal systems, based on both native and raw non-native, mostly herbal but also mineral, and some animal-derived ingredients, along with therapies such as cupping and gold-needle moxibustion, related diagnostic modes of pulse and urine examination, breathing and physical exercises, as well as internal visualizations [5]. Tibetan medicine existentially depends on the translational flows of raw materials, knowledge and expertise, products, and people [45].

The main raw ingredients of Tibetan medicine are plants, minerals, and animal parts, mostly from natural and wild sources. Many raw materials used in Tibetan medicine are not native to Tibet and sourced at domestic as well as the cross-border level 
[6]. Medicinal plants imported from India and Nepal constitute a considerable part of Tibetan medicine's materia medica. Therefore, the cross-border movement of merchants [1] and medicinal plants across spatial and conceptual borders has been essential to Tibetan medicine since ancient times. As for domestic sourcing, traditional Tibetan medicinal practitioners (Amchis) used to collect wild medicinal plants from the Tibetan pastures, such as Aconitum heterophyllum Wall. ex Royle, Rhodiola crenulata (Hook. f. \& Thomson) Saxifraga sp., Nardostachys jatamansi (D. Don) DC. [6].

Cross-border sourcing mostly occurred from the tropical and sub-tropical regions of Nepal and India via the trans-Himalayas for medicinal plants like Terminalia chebula Retz., Terminalia bellirica (Gaertn.) Roxb., and Phyllanthus emblica L. These three fruits collectively form an indispensable part of Tibetan pharmacy and can be found in the majority of Tibetan formulas [6]. T. chebula, the myrobalan fruit, is also the most widely used symbol in Tibetan medicine. Later, Swertia chirayita (Roxb.) Buch.-Ham.ex C. B. Clarke, red and white sandal wood, and other medicinal plant products were traded through cross-border sources including minerals like Shilajit (a black mineral available in the highest Himalayas) $[6,46]$. Wildlife products such as the skins and bones of leopards and tigers, otter pelts, musk pods, bear bile, and the gallstones of buffalo and elephants have been traded from the lower plains of Nepal and India via the trans-Himalayas to Tibet as medicinal ingredients [6]. Tibetans used to visit the Kathmandu Valley (Nepal) in the wintertime to exchange salt, yak tails, and woollen blankets for grain, and also dealt in gold dust, turquoise, agate, rubies, and other precious stones, together with medicinal plants [1].

During the eighth and seventeenth centuries, transHimalayan trade from Nepal to Tibet was conducted around 18 trans-Himalayan trade routes, and from 904-1962 via Sikkim, India $[1,2,47,48,49]$. The Kyirong Pass was the shortest route to the Tibetan capital, Lhasa [47]. Despite the adverse topography, weather conditions, and the constant threat of attack by gangs of armed bandits along the way, long caravans transported edible goods, cloth, metal utensils, and religious Buddhist items from Nepal. Silk, gold powder, yak tails, salt, etc. were transported from Lhasa and beyond [50]. Many Nepalese traders enjoyed certain privileges in Tibet like marrying Tibetan women. Their male children were regarded as Nepalese, whereas female children were acknowledged as Tibetan citizens [51]

Evidence of the centuries-old medicinal plant trade from Nepal to China has been provided by researchers such as Hamilton [8], Kirkpatrick [9], and Dobremez [7]. During the 1970s, the medicinal plant trade helped to increase foreign earnings with the main exporting countries being Belgium, France, the U.K., Canada, Hong Kong, Japan, and Singapore [14]. The continuous trade in medicinal plant from Nepal to China during the late twentieth and early twenty-first century has been evidenced by researchers like Edwards (1996), He et al. [22], Pyakurel \& Panthi [23], Olsen [10], and Saxer [3].

The Nepal-China trade has a long history. Following the trading trajectories across the Himalayas, medicinal plant commodities were assembled and supplied from Nepal through the Himalayan land paths and sourced and consumed in Tibet within the complex channels of institutional and private trade. Due to its biodiversity and huge altitudinal range of 60-8848masl, many of the necessary ingredients of Tibetan medicine were available in Nepal. Consequently, a barter system for Himalayan trade existed between Nepal and Tibet. Generally, this consisted of animal products (silk, yak tails), salt (formed in natural lakes) from the Tibetan plateau, food grain, metal utensils, and religious Buddhist items including medicinal plants from Nepal. Such resource management in the past has led to medicinal plants becoming essential components of Himalayan trade from Nepal to China.

\section{Comprehensive Overview of Species Traded from}

\section{Nepal to China}

According to the literature review, 13 studies mentioned the names and final destinations of species traded from Nepal to China. He et al. [22] (reported number of species traded to China, $\mathrm{n}=17$ ); Pyakurel \& Panthi [23], and Saxer [3] (each n=8); PSCN [24] $(n=6)$; Acharya [52] $(n=3)$; Sherpa [53] and van Boeckel [54] (each n=2); Amatya [55]; Cunningham et al. [56]; Devkota \& Shrestha [57]; GoN[58]; IFA [59], and Phoboo and Jha [60] (each $\mathrm{n}=1$ ).

\section{Overview of Nepalese medicinal plants traded to China}

Fifty-four Nepalese medicinal plant species of 48 genera under 41 families are recorded as being traded to China since ancient times. Orchidaceae is the largest family with four species, followed by Asparagaceae and Ranunculaceae (each with three species) and Berberidaceae, Combretaceae, Elaeocarpaceae, Eleagnaceae, Gentianaceae, and Lauraceae (each with two species). The remaining 32 families have one species each (Appendix I).

Most medicinal plants exported to China from Nepal are herbs (22 species contributing to $44.4 \%$ ) (perennial herbs-19, annual herbs-1, herbaceous climbers-2, epiphytic herbs-1, saprophytic herbs-1), 14 are trees (25.9\%) (small trees-8, trees-1, large trees-5), 10 are shrubs (18.5\%) (small shrubs-2, shrubs-8), three are fungi (5.5\%), 1 lichen (1.8\%), and 2 others $(3.7 \%)$ (pteridophyte-1, small tree/shrub-1) (Figure 1).

About $80 \%$ of the investigated medicinal plant species grow in native wild form and $15 \%$ in native wild and cultivated form in Nepal. Two species are exotic cultivars and one a native cultivar (Appendix I).

\section{Conservation status of investigated species}

Generally, underground parts (roots, rhizomes, and bulbs), bark, fruits, seeds, flowers, leaves, and twigs are traded as medicinal plants. However, these are often harvested by uprooting 
the whole plant [61]. About 59\% of the investigated medicinal plant species are harvested for the whole plant, underground parts, bark, wood, or stem, compared to $50 \%$ for the underground parts, whole plant, or bark [2019], and 41\% harvested for leaves, twigs, fruit, seeds, flowers, or resin (Appendix I). The harvesting pattern of underground parts, the whole plant, or bark for the collection of large quantities of plant material is considered destructive [62] compared to the harvesting pattern of fruits, seeds, flowers, leaves, and twigs [63].

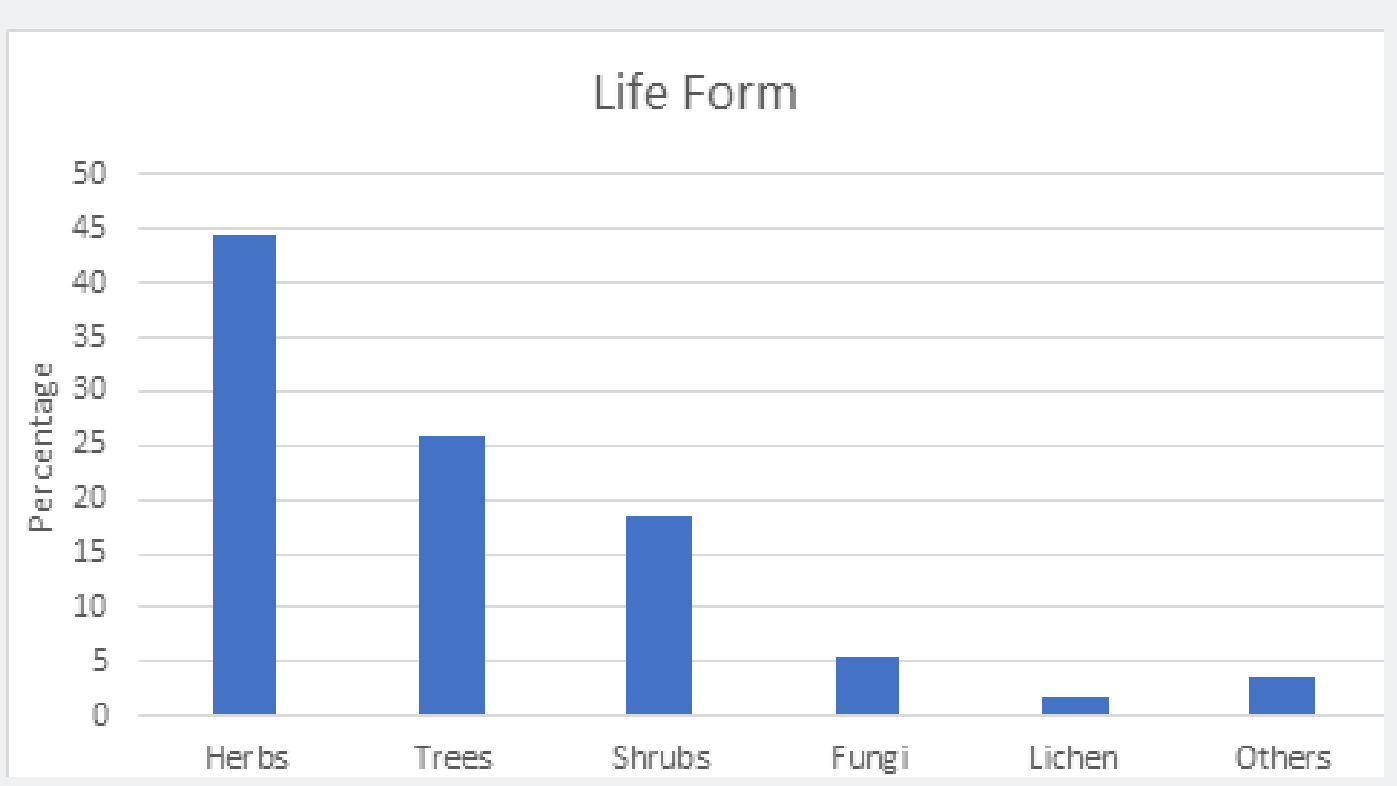

Figure 1: Life form of investigated medicinal plants

Of the 54 investigated species traded from Nepal to China, 26 (48.15\%) are included in one or more national (CAMP [38], $n=16$ and GoN [40], $n=5$ ) or international (IUCN [37], $n=7$ and CITES [39], $n=4$ ) conservation lists (Appendix I). Four species of orchids are traded, with all orchids kept under the CITES threat category (Appendix I). Nardostachys jatamansi (D. Don) DC. (jatamansi, bhutle/pangpö/spikenard) of the Valerianaceae family is listed in all four categories. Dactylorhiza hatagirea (D. Don) Soó (Panchaunle, Hatajadi/Salep, Marsh Orchid) of the Orchidaceace family is listed in three of the conservation categories. Four species are listed in two conservation categories and the remaining 20 species in at least one (Appendix I).

\section{Medicinal plant exports}

The medicinal plants exported from Nepal to China are proportionally high in both volume and value compared to India and other countries (Figure 2). This is due to the trade in Yarsagumba (Ophiocordyceps sinensis). Yarsagumba, also referred to as Himalayan Viagra, is a caterpillar fungus, endemic to the high Himalayas and Tibetan plateaus, used in Tibetan and Chinese medicine and in great demand by China [64]. Pouliot et al. [64] reported that a single $5 \mathrm{~cm}$ long piece of fungus-caterpillar, weighing a fraction of a gram, is being retained for as much as 50 USD in China, more than the price of gold on the international market. Due to its high demand and strict host-specificity deterioration, this species has been kept in the vulnerable category by IUCN for 2020. According to UN COMTRADE data from 2013 to 2017, on average, China imported 555.5 tons of medicinal plants annually, worth USD 3.34 million, India imported 3,633.3 tons worth USD 3.97 million, while other countries imported 382.2 tons worth USD 1.00 million.

\section{Enumerated species}

The medicinal plant species traded from Nepal to China, in increasing order, are almost twice the figures estimated by Saxer [3:107] and thrice that estimated by Pyakurel \&Panthi [23] and He et al. [22]. China's per capita income from 1996 to 2018 increased 13.8-fold [65] due to the continued consumer demand for medicinal plants, fungi, and lichen [20]. Some of this increase came from enumerating product groups at the species level, for example, the two species of Polygonatum traded as Setak Chini/ Khiraula, similarly the two species of Berberis traded as Chutro, and the two species of Hippophae traded as sea buckthorn. The significant demand for new species such as the recently traded Ganoderma lucidum (Curtis) P. Karst, and Dendrobium nobile Lindl. [20,22] has also increased the number of medicinal plants traded from Nepal to China. 


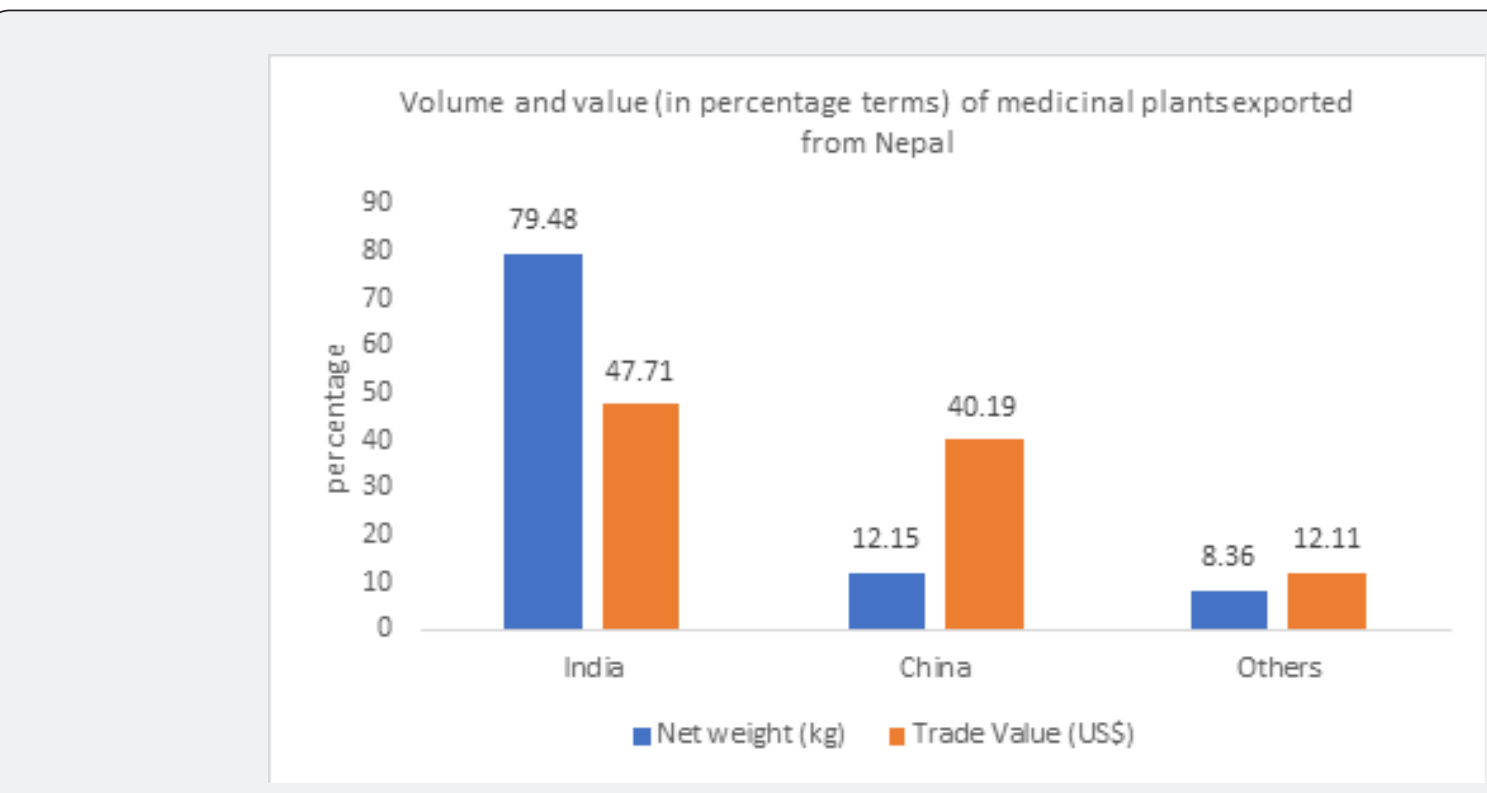

Figure 2: Volume and value (in percentage terms) of medicinal plants exported from Nepal to India, China and other countries.

\section{Demand Drivers of Nepalese Medicinal Plants in China}

\section{Industrialization of tibetan medicine}

After the incorporation of Tibetan regions into the People's Republic of China in 1949, the Tibetan culture, customs, and traditional medicine were destroyed during the Cultural Revolution. However, since 1975, with religious freedom alongside economic and other reforms, Tibetan medicine and pharmaceuticals have been revived in the Tibetan Autonomous Region (TAR) and western provinces of China, creating a medical treasure house for the motherland [42]. The revival of Tibetan medicine was based on the interests of the Chinese state to show respect for local culture and customs, with the added value of serving the primary health care needs of rural populations. Thus, the state did not simply rebuild previously destroyed medical establishments and support practitioners, but integrated Tibetan medicine with biomedicine [42].

The Chinese Medical Association Society in Lhasa organized the first modern conference during 1981 on the international exchange of theoretical and clinical experiences relating to Tibetan medical history, theory, clinical practice, various prescriptions, and the scientific research of experts and physicians. In 1991, the modern Tibetan Materia Medica codified the identification of raw medicinal plants and over 100 types of medicinal ingredients with 600 different Tibetan treatments. By the end of 1993, the PRC regulation of standards and quality control in production emerged as the Central Ministry of Health Drug Standards Office [43]. These measures led to the rapid process of modernization of traditional Tibetan medicine during the 1980s and 1990s with new theories and practices $[3,41]$. Tibetan medical efficacy is found to be equivalent to modern scientific methods [43]. Tibetan medical schools and family traditions outside China continued in much the same way as the pre-modern structure of Tibetan medical knowledge [5]. The state-sponsored revitalization of Tibetan medicine continued in hospitals and medical colleges, with production growing in urban centers, after China's shift toward a "socialist market economy" in 1992 began to yield profit and a wider market [4:9]. Private Amchis actively contributed to re-establish meaningful social and medical networks, knowledge transmission, and practices. Some of them promoted government clinics and colleges and served as health workers in villages [42].

In 2001, a drug administration law was introduced for drug registration, with a mandate to implement GMP-certification for all commercial pharmaceutical producers. As a result, by the end of 2004, the establishment of GMP-certified Tibetan medicine industry resulted in the significant expansion of trans-Himalayan medicinal plant trade [3].

With the establishment of these policies for traditional medicine in China, the Tibetan medicine industry has become one of the most important resources in China, constituting an economic and public health backbone for entire regions since the early 2000s. According to Kloos et al. [4:10], 281 Tibetan medicine hospitals operate at various levels (e.g., international, national, provincial, county, and city) in China. China controls 97.74\% of the Tibetan medicine industry in Asia, generating an annual sales value of 662.2 million USD in 2017 [4:7]. Over 40 GMP-certified Tibetan medicine pharmaceuticals established in China. The Tibet Autonomous Region (TAR) consists of 18 GMPcertified producers, generating about 236 million USD from 
Tibetan medicine in 2017 [4:11]. Furthermore, the TAR and other Chinese provinces also have GMP-certified manufacturers. For instance, Sichuan has nine, worth about 10 million USD in 2017 while Yunnan has one private commercial producer. Qinghai has 14 certified manufacturers worth about 77.4 million USD in 2017, while Gansu also a few, worth about 18.6 million USD in 2017.

Although the factories are in the TAR and mainland China, Tibetan medicine products reach beyond Tibet and China to neighboring countries (India, Bhutan, Russia), Western Europe (Switzerland), and America. As a result, Tibetan medical schools and family traditions have spread beyond China. In the past, the raw ingredients were traded for preparing handmade pills and powders but nowadays both raw and ready-made ingredients like powder, pills, oils etc. are traded for Tibetan Medicine factory with high-tech stainless-steel machine to dry ingredients, grind and sort pills.

The industrialization of Tibetan medicine has significantly increased the demand for plants from both low altitude and highaltitude medicinal plants (available between the altitudinal range from 3,700 to 5,000 meters or above) [66]. It is believed that the species grown in a particular range of altitude maintain the same medicinal qualities, then the species grown in lower or higher than that range, as the size, shape, function and medical potency can differ even with the same species [66] as mentioned in The Four Tantras. Nepal Himalayas with altitudinal range from 60 to $8848 \mathrm{~m}$ asl is home to more than 2,300 medicinal plants [19] from low to high altitudes, mostly collected from wild resources with higher medicinal efficiency, and alternative substitutes of related varieties for endangered species might be the major reasons for the alternative supply of Nepalese Medicinal plants for Tibetan medicinal industries.

\section{Nepalese medicinal plants market in China beyond Tibetan Medicine}

Besides, the raw ingredients for modernized Tibetan Medicine Industry, the other demand drivers of Nepalese medicinal plants in China are globalization of the medicinal plant trade (re-export) $[11,12]$, where they are the subject of increasing interest in the herbal curative system [14] which has few or no side effects and increased herbal market with modern technologies and infrastructures. This high demand may be due to the significant efficiency [15] of bio-constituents in modern medicine due to the availability of high bioactive compounds, medicinal efficiency to Traditional Chinese Medicine [16] or their use in the preparation of aromatic products, cosmetics, plant fibers, herbal dyes, food flavoring [17], gifts, food supplements, herbal teas, massage oils, etc. or consumed at Chinese retail markets.

For instance, China is the highest exporter and the fourth highest importer in terms of trade volume, while Nepal is the fourth major exporter to China (in terms of trade value) and China has the second largest economy. China's high GDP annual growth rate $(\sim 6 \%)$ and high per capita income $(9,770.85$ USD in 2018) [65] have resulted in consumer behavior changes and a shift to herbal from conventional medicine and an increase in the Nepalese medicinal plant trade with China.

However, medicinal plants exports to China are hampered by transportation costs, Chinese regulations (such as the 2008 licensing system established by Beijing, which requires a separate license to be obtained for each herb) and the inability to compete on price with similar local goods [67]. The governments of China and Nepal developed a set of strict rules and regulations, by which all the traders in the trans-Himalayan belt road had to abide. For instance, the provisions of Forest Regulation (1995) in Nepal included restrictive procedures such as permits for collection and release, certificates of origin, export licenses, export duty, and phytosanitary certificates from related government authorities for the export of medicinal plants. Besides, Nepal and China both signed the Convention on International Trade in Endangered Species of Wild Fauna and Flora (CITES, 1975) to monitor and regulate international trade on endangered and rare species.

Recently, the numerous bilateral agreements on trans-border trade in traditional medicine have been initiated, and high medicinal plants are expected to experience high mobility due to the modernization of medicinal plant-based industries in China helping to maintain sustainable trade in Himalayan medicinal plants with equitable benefit sharing.

\section{Conclusion}

Medicinal plants from Nepal have been traded toward Tibet for centuries with more medicinal and cultural functions. In contrast, the present Nepalese medicinal plant trade to China is more economical due to the availability of high bioactive compounds, medicinal efficiency, ancient medication systems (Tibetan and traditional Chinese medicine), preparation of aromatic products, cosmetics, plant fibers, herbal dyes, food, flavors, gifts, etc.

The extensive trade in medicinal plants toward China is due to the industrialization of traditional medicine, interest in the herbal curative system which has few or no side effects and increased herbal market with modern technologies and infrastructures. The trade sustainability should be addressed considering the research and promotion on cultivation of high demand plants with certified medicinal efficiency, provisions on sustainable collection, transport, export and import regulation by both countries, research on alternative substitutes, utilization of local knowledge for resource-based industry, promotion of traditional medicine, markets and semi processed products .

With the industrialization of Tibetan medicine, globalization of the medicinal plant trade, growing Chinese traditional market and access to modern transportation (roadways, seaways, and airways), Nepalese medicinal plants are traded beyond Tibet for economic purposes. Improving Nepal-China relations with Nepal's 
agreement on the Chinese Belt and Road Initiative (BRI), TransHimalayan Multi-dimensional Connectivity Network (THMDNC) under BRI and its cooperation concerning the development of traditional medicine during President Xi's state visit to Nepal in 2019 are expected to amplify the Nepalese medicinal plant trade, providing the opportunity for national economic development.

\section{Acknowledgement}

The researchers would like to thank local officials at the Divisional Forest Office of Kathmandu, Sindhupalchowk and Sankhuwasabha, members of the Herbal Entrepreneur
Association Nepal (HEAN), the Nepal Herbs and Herbal Products Association (NEHHPA), Federation of Community Forestry Users Nepal (FECOFUN) and its district chapters, and the Transiting to Green Growth-Nepal (TGG-N) project at FECOFUN for providing information on the medicinal plant trade and traded species in 2016. The researchers are grateful to Carsten Smith-Hall, Linda Li and Laxmi Raj Joshi for their valuable suggestions on an earlier version of the manuscript. The researchers are also thankful to research committee of City University of Hong Kong and the Department of National Parks and Wildlife Conservation, Government of Nepal for issuing research permission.

Appendix I: Medicinal Plant species traded from Nepal to China.

\begin{tabular}{|c|c|c|c|c|c|c|c|c|c|c|}
\hline S.No. & Family & Scientific Name & $\begin{array}{l}\text { English } \\
\text { Name }\end{array}$ & $\begin{array}{l}\text { Nepali (N), } \\
\text { Tibetan (T) } \\
\text { and Chinese } \\
\text { (C) Name }\end{array}$ & $\begin{array}{l}\text { Life } \\
\text { Form }\end{array}$ & $\begin{array}{l}\text { Parts Trad- } \\
\text { ed }\end{array}$ & $\begin{array}{l}\text { Occur- } \\
\text { rence } \\
\text { Status }\end{array}$ & $\begin{array}{l}\text { Distribution } \\
\text { in Nepal (m) }\end{array}$ & $\begin{array}{l}\text { Threat } \\
\text { Status }\end{array}$ & Source \\
\hline 1 & $\begin{array}{l}\text { Anacardia- } \\
\text { ceae }\end{array}$ & $\begin{array}{l}\text { Pistacia chinensis } \\
\text { subsp. integerrima } \\
\text { (J. L. Stewart) } \\
\text { Rech. f. }\end{array}$ & $\begin{array}{l}\text { Insect Gall in } \\
\text { Pistacia }\end{array}$ & $\begin{array}{l}\text { Kakadsinghi } \\
\text { (N) }\end{array}$ & ST & Leaf, twig & Nat-W & $\begin{array}{l}\text { W (600- } \\
2400)\end{array}$ & & $\begin{array}{l}\text { Field Sur- } \\
\text { vey [32] }\end{array}$ \\
\hline 2 & Araliaceae & $\begin{array}{l}\text { Panax pseudogin- } \\
\text { seng Wall. }\end{array}$ & Wild Potato & $\begin{array}{c}\text { Saatgath / } \\
\text { Ban Aalu (N) }\end{array}$ & $\mathrm{PH}$ & $\begin{array}{l}\text { Underground } \\
\text { Part }\end{array}$ & Nat-W & $\begin{array}{c}\text { CE } \\
(2100-3800)\end{array}$ & CAMP-V & $\begin{array}{c}\text { DFO KTM } \\
{[34]}\end{array}$ \\
\hline 3 & $\begin{array}{l}\text { Asparaga- } \\
\text { ceae }\end{array}$ & $\begin{array}{l}\text { Polygonatum cir- } \\
\text { rhifolium (Wall.) } \\
\text { Royle }\end{array}$ & & $\begin{array}{l}\text { Setakchini / } \\
\text { Khiraulo (N) }\end{array}$ & $\mathrm{PH}$ & $\begin{array}{l}\text { Underground } \\
\text { part }\end{array}$ & Nat-W & $\begin{array}{c}\text { WCE } \\
(1230-4600)\end{array}$ & & $\begin{array}{c}\text { DFO KTM } \\
{[34]}\end{array}$ \\
\hline 4 & $\begin{array}{l}\text { Asparaga- } \\
\text { ceae }\end{array}$ & $\begin{array}{l}\text { Polygonatum verti- } \\
\text { cillatum (L.) All. }\end{array}$ & & $\begin{array}{l}\text { Setakchini / } \\
\text { Khiraulo (N) }\end{array}$ & PH & $\begin{array}{l}\text { Underground } \\
\text { part }\end{array}$ & Nat-W & $\begin{array}{c}\text { WCE } \\
(2700-4700)\end{array}$ & & $\begin{array}{c}\text { DFO KTM } \\
{[34]}\end{array}$ \\
\hline 5 & $\begin{array}{l}\text { Asparaga- } \\
\text { ceae }\end{array}$ & $\begin{array}{l}\text { Asparagus race- } \\
\text { mosus Willd. }\end{array}$ & & $\begin{array}{l}\text { Kurilo/Sa- } \\
\text { tawari (N) }\end{array}$ & $\mathrm{SSH}$ & $\begin{array}{l}\text { Underground } \\
\text { part }\end{array}$ & Nat-C\&W & $\begin{array}{c}\text { WCE } \\
(100-2200)\end{array}$ & CAMP-V & $\begin{array}{c}\text { DFO KTM } \\
{[34]}\end{array}$ \\
\hline 6 & Asteraceae & $\begin{array}{l}\text { Artemisia indica } \\
\text { Willd. }\end{array}$ & & Titepati (N) & SSH & Leaf, twig & Nat-W & $\begin{array}{c}\text { (WCE } \\
180-3100)\end{array}$ & & $\begin{array}{c}\text { DFO KTM } \\
{[34]}\end{array}$ \\
\hline 7 & $\begin{array}{l}\text { Berberida- } \\
\text { ceae }\end{array}$ & $\begin{array}{c}\text { Berberis aristata } \\
\text { DC. }\end{array}$ & & Chutro (N) & $\mathrm{SH}$ & Bark, Wood & Nat-W & $\begin{array}{c}\text { WC } \\
(1150-4000)\end{array}$ & & $\begin{array}{c}\text { DFO KTM } \\
{[34]}\end{array}$ \\
\hline 8 & $\begin{array}{l}\text { Berberida- } \\
\text { ceae }\end{array}$ & $\begin{array}{l}\text { Berberis asiatica } \\
\text { Roxb. ex DC. }\end{array}$ & & Chutro (N) & SH & Bark, Wood & Nat-W & $\begin{array}{c}\text { WCE } \\
(650-3150)\end{array}$ & & $\begin{array}{c}\text { Field } \\
\text { Survey } \\
{[32]}\end{array}$ \\
\hline 9 & $\begin{array}{l}\text { Bignonia- } \\
\text { ceae }\end{array}$ & $\begin{array}{l}\text { Oroxylum indicum } \\
\text { (L.) Kurz. }\end{array}$ & & Tatelo (N) & ST & Bark, Seed & Nat-W & $\begin{array}{c}\text { WCE } \\
(300-1400)\end{array}$ & $\begin{array}{l}\text { CAMP- } \\
\text { EN }\end{array}$ & $\begin{array}{c}\text { DFO KTM } \\
{[34]}\end{array}$ \\
\hline 10 & $\begin{array}{l}\text { Caprifolia- } \\
\quad \text { ceae }\end{array}$ & $\begin{array}{l}\text { Nardostachys jata- } \\
\text { mansi (D.Don) DC. } \\
\text { Syn: Nardostachys } \\
\text { grandiflora Wall. } \\
\text { ex DC. } \\
\text { grandiflora Wall. } \\
\text { ex DC. }\end{array}$ & Spikenard & $\begin{array}{l}\text { Jatamansi / } \\
\text { Bhutle (N); } \\
\text { Pangpö, } \\
\text { spang spos } \\
\text { (T); 甘松香 } \\
\text { (C) }\end{array}$ & ST & $\begin{array}{l}\text { Und_prt, } \\
\text { Rhizome }\end{array}$ & Nat-W & $\begin{array}{c}\text { WCE } \\
(3200-5000)\end{array}$ & $\begin{array}{l}\text { GoN-RE, } \\
\text { CAMP-V; } \\
\text { IUCN-CR; } \\
\text { CITES II }\end{array}$ & $\begin{array}{c}\text { Acharya } \\
\text { [52]; } \\
\text { Saxer [3]; } \\
\text { He et al. } \\
\text { [22] }\end{array}$ \\
\hline 11 & $\begin{array}{l}\text { Combreta- } \\
\text { ceae }\end{array}$ & $\begin{array}{l}\text { Terminalia belliri- } \\
\text { ca (Gaertn.) Roxb. }\end{array}$ & $\begin{array}{l}\text { Belleric } \\
\text { Myrobolan }\end{array}$ & $\begin{array}{l}\text { Barro (N); } \\
\text { Barura (T) }\end{array}$ & LT & $\begin{array}{l}\text { Fruit, Seed, } \\
\text { Bark }\end{array}$ & Nat-W & $\begin{array}{c}\text { CE } \\
(100-1100)\end{array}$ & & $\begin{array}{c}\text { Saxer [3]; } \\
\text { Field Sur- } \\
\text { vey [32] }\end{array}$ \\
\hline
\end{tabular}


International Journal of Environmental Sciences \& Natural Resources

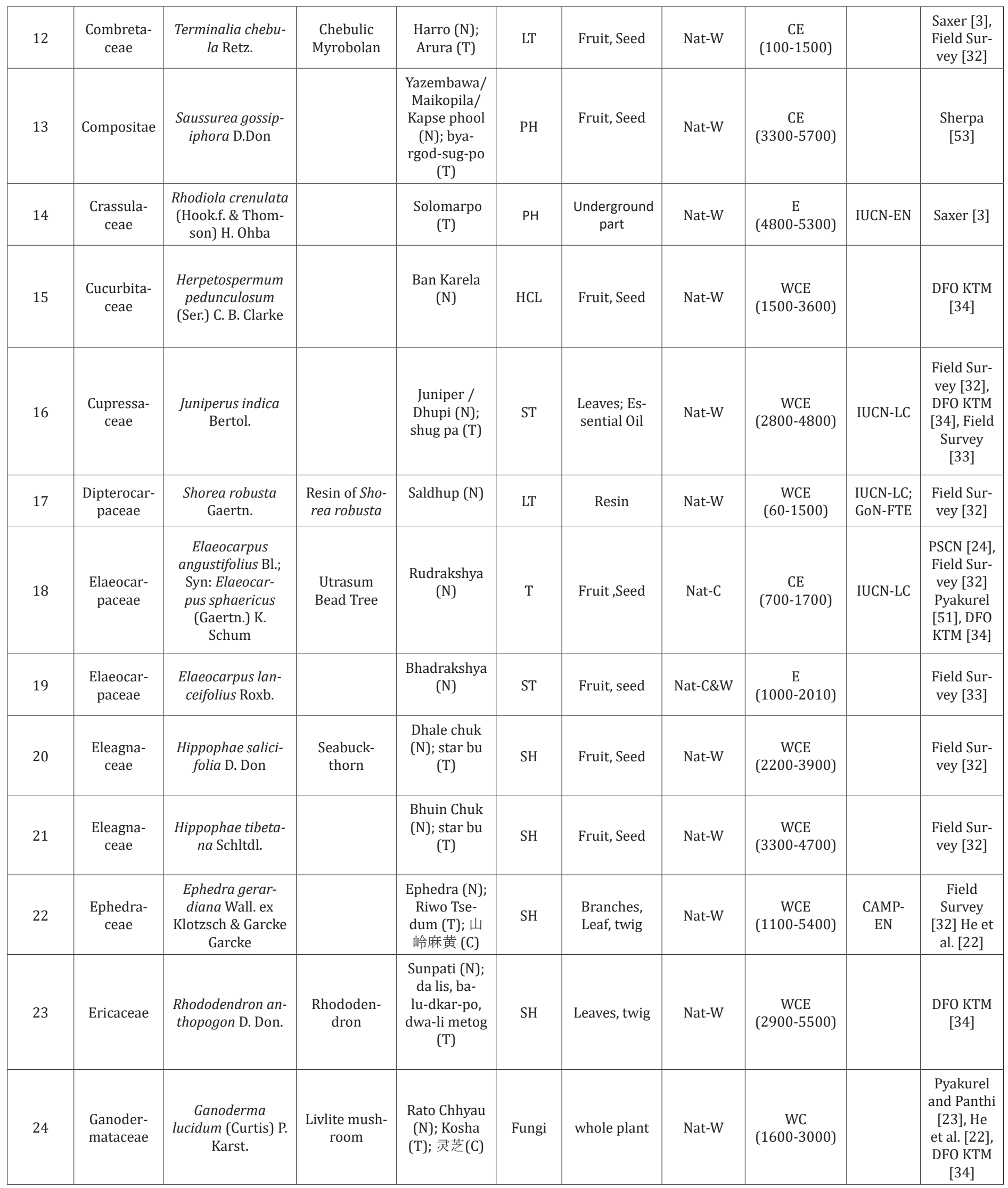


International Journal of Environmental Sciences \& Natural Resources

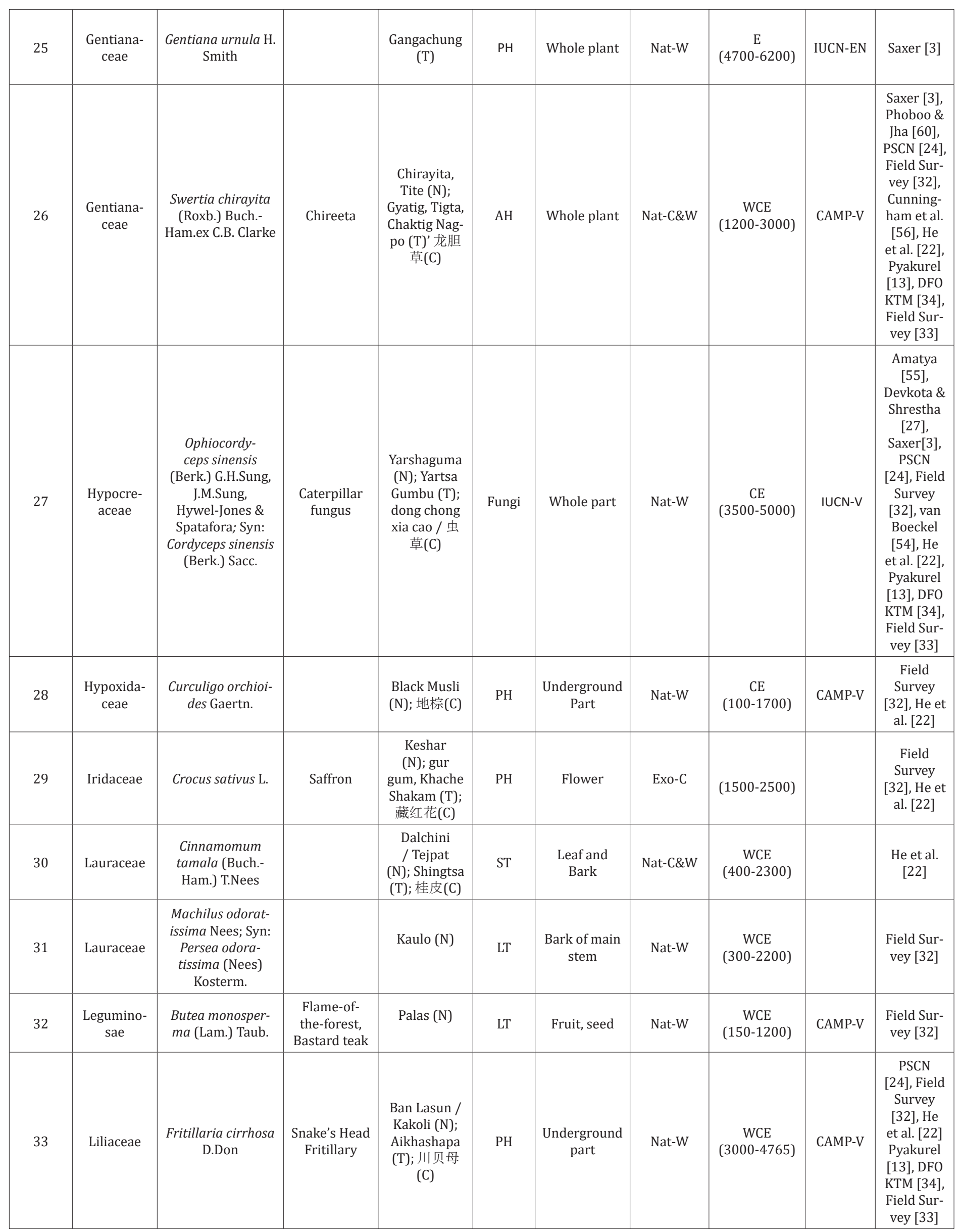


International Journal of Environmental Sciences \& Natural Resources

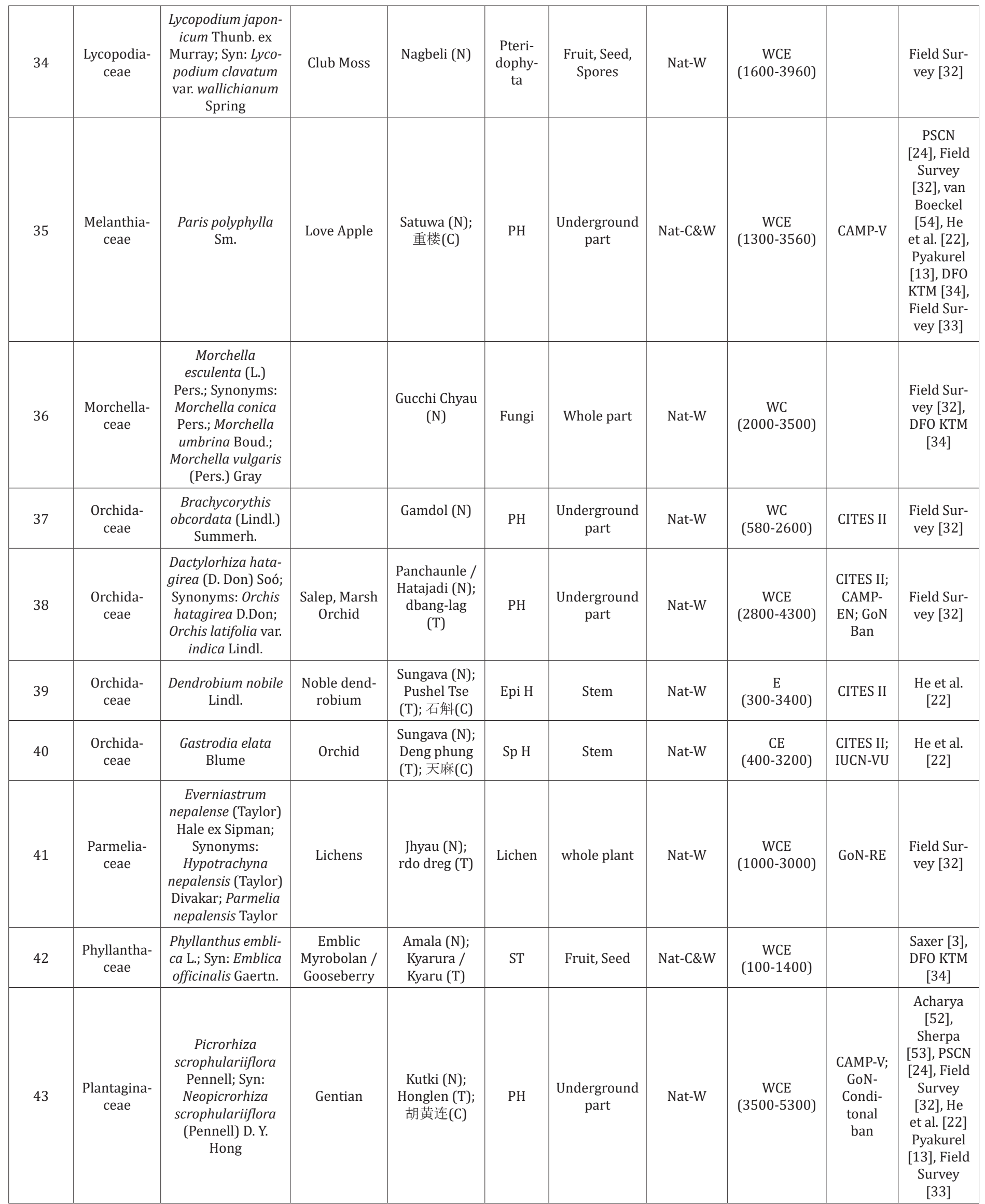




\begin{tabular}{|c|c|c|c|c|c|c|c|c|c|c|}
\hline 44 & $\begin{array}{l}\text { Polygona- } \\
\text { ceae }\end{array}$ & $\begin{array}{l}\text { Rheum australe } \\
\text { D. Don }\end{array}$ & $\begin{array}{l}\text { Himalayan } \\
\text { Rhubarb }\end{array}$ & $\begin{array}{l}\text { Padamchaal } \\
\text { (N); Chum } \\
\text { Tsa (T); 藏边 } \\
\text { 大黄(C) }\end{array}$ & $\mathrm{PH}$ & $\begin{array}{l}\text { Underground } \\
\text { part, Leaf, } \\
\text { twig }\end{array}$ & Nat-W & $\begin{array}{c}\text { WCE } \\
(2700-4400)\end{array}$ & CAMP-V & $\begin{array}{c}\text { Field } \\
\text { Survey } \\
{[32], \text { He et }} \\
\text { al. [22] }\end{array}$ \\
\hline 45 & $\begin{array}{l}\text { Primula- } \\
\text { ceae }\end{array}$ & $\begin{array}{c}\text { Embelia ribes } \\
\text { Burm. F }\end{array}$ & & $\begin{array}{c}\text { Kalikath } \\
\text { ko geda, } \\
\text { Bayobiding, } \\
\text { Kaladana (N) }\end{array}$ & SH & Fruit, Seed & Nat-W & $\begin{array}{c}\text { WCE } \\
(400-1600)\end{array}$ & & $\begin{array}{c}\text { DFO KTM } \\
{[34]}\end{array}$ \\
\hline 46 & $\begin{array}{l}\text { Ranuncula- } \\
\text { ceae }\end{array}$ & $\begin{array}{c}\text { Delphinium } \\
\text { himalayae Munz; } \\
\text { Syn: Delphinium } \\
\text { himalayense } \\
\text { Chowdhury ex } \\
\text { Mukerjee }\end{array}$ & Aconite Root & $\begin{array}{c}\text { Atis Root } \\
\text { (N); Bongkar, } \\
\text { bya rkang (T) }\end{array}$ & $\mathrm{PH}$ & $\begin{array}{l}\text { Underground } \\
\text { Part }\end{array}$ & Nat-W & $\begin{array}{c}\text { WC } \\
(2000-4550)\end{array}$ & $\begin{array}{l}\text { CAMP-V; } \\
\text { IUCN-R }\end{array}$ & $\begin{array}{c}\text { Acharya } \\
\text { [52], Field } \\
\text { Survey } \\
\text { [32], He } \\
\text { et al. [22], } \\
\text { DFO KTM } \\
\text { [34] }\end{array}$ \\
\hline 47 & $\begin{array}{l}\text { Ranuncula- } \\
\text { ceae }\end{array}$ & $\begin{array}{l}\text { Delphinium } \\
\text { denudatum Wall. } \\
\text { ex. Hook. f. \& } \\
\text { Thomson }\end{array}$ & Larkspur & $\begin{array}{l}\text { Nirmasi }(\mathrm{N}) \text {; } \\
\text { bya rkang }(\mathrm{T})\end{array}$ & $\mathrm{PH}$ & $\begin{array}{l}\text { Underground } \\
\text { Part }\end{array}$ & Nat-W & $\begin{array}{c}\text { WC } \\
(1500-3000)\end{array}$ & & $\begin{array}{c}\text { Field Sur- } \\
\text { vey [32], } \\
\text { DFO KTM } \\
{[34]}\end{array}$ \\
\hline 48 & $\begin{array}{l}\text { Ranuncula- } \\
\text { ceae }\end{array}$ & $\begin{array}{l}\text { Aconitum palma- } \\
\text { tum D. Don; Syn: } \\
\text { Aconitum bisma } \\
\text { (Buch.-Ham.) } \\
\text { Rapaics }\end{array}$ & & Bikhma (N) & $\mathrm{PH}$ & $\begin{array}{l}\text { Underground } \\
\text { Part }\end{array}$ & Nat-W & $\begin{array}{c}\text { CE } \\
(3200-4500)\end{array}$ & $\begin{array}{l}\text { CAMP- } \\
\text { DD }\end{array}$ & $\begin{array}{l}\text { Field Sur- } \\
\text { vey [33] }\end{array}$ \\
\hline 49 & $\begin{array}{l}\text { Rhamna- } \\
\text { ceae }\end{array}$ & $\begin{array}{l}\text { Ziziphus xiang- } \\
\text { chengensis Y. } \\
\text { L. Chen and P. } \\
\text { K. Chou; Syn: } \\
\text { Ziziphus budhensis } \\
\text { K.R. Bhattarai and } \\
\text { Pathak } \\
\end{array}$ & & $\begin{array}{l}\text { Buddha Chit- } \\
\text { ta, Bodhichit- } \\
\text { ta (N) }\end{array}$ & $\mathrm{ST} / \mathrm{SH}$ & Fruit, seed & Exo-C & $(1200-2000)$ & & $\begin{array}{c}\text { IFA [59], } \\
\text { DFO KTM } \\
{[34]}\end{array}$ \\
\hline 50 & Rosaceae & $\begin{array}{l}\text { Argentina lineata } \\
\text { (Trevir.) Soják; } \\
\text { Synonyms: Poten- } \\
\text { tilla fulgens Wall. } \\
\text { ex Hook.; Potentil- } \\
\text { la lineata Trevir }\end{array}$ & $\begin{array}{l}\text { Cinquefoil, } \\
\text { Silver Leaf }\end{array}$ & $\begin{array}{l}\text { Bajradanti } \\
\text { (N); Dumbu } \\
\text { Rerel (T); 管 } \\
\text { 仲 (C) }\end{array}$ & $\mathrm{PH}$ & Root & Nat-W & $\begin{array}{c}\text { WCE } \\
(1700-4100)\end{array}$ & & $\begin{array}{c}\text { Field } \\
\text { Survey } \\
\text { [32], He et } \\
\text { al. [22] }\end{array}$ \\
\hline 51 & Rubiaceae & $\begin{array}{c}\text { Rubia manjith } \\
\text { Roxb. ex Fleming }\end{array}$ & Madder & $\begin{array}{l}\text { Majitho } \\
\text { (N); Tsöpa } \\
\text { (T); 茜草(C) }\end{array}$ & HCL & Root, Stem & Nat-W & $\begin{array}{c}\text { WCE } \\
(1100-2900)\end{array}$ & CAMP-V & $\begin{array}{l}\text { Field Sur- } \\
\text { vey [32], } \\
\text { He et al. } \\
\text { [22], DFO } \\
\text { KTM [34] }\end{array}$ \\
\hline 52 & Rutaceae & $\begin{array}{l}\text { Zanthoxylum } \\
\text { armatum DC. }\end{array}$ & $\begin{array}{l}\text { Nepalese } \\
\text { Pepper }\end{array}$ & Timur (N) & SH & Fruit, Seed & Nat-C \& W & $\begin{array}{c}\text { WCE } \\
(730-3100)\end{array}$ & & $\begin{array}{c}\text { GoN [58], } \\
\text { Pyakurel } \\
\text { \& Panthi } \\
\text { [23], Field } \\
\text { Survey } \\
\text { [32], He et } \\
\text { al. [22] }\end{array}$ \\
\hline 53 & $\begin{array}{l}\text { Sapinda- } \\
\text { ceae }\end{array}$ & $\begin{array}{l}\text { Sapindus mukoros- } \\
\text { si Gaertn. }\end{array}$ & $\begin{array}{l}\text { Soapnut, } \\
\text { Beads, Soap- } \\
\text { berry }\end{array}$ & Ritha (N) & ST & Fruit, Seed & Nat-C \& W & $\begin{array}{c}W \\
(900-1700)\end{array}$ & & $\begin{array}{l}\text { Field Sur- } \\
\text { vey [32] }\end{array}$ \\
\hline 54 & $\begin{array}{l}\text { Saxifraga- } \\
\text { ceae }\end{array}$ & $\begin{array}{l}\text { Bergenia ciliata } \\
\text { (Haw.) Sternb. }\end{array}$ & Rockfoil & $\begin{array}{l}\text { Pakhanbed } \\
\text { (N) }\end{array}$ & $\mathrm{PH}$ & $\begin{array}{l}\text { Underground } \\
\text { Part }\end{array}$ & Nat-W & $\begin{array}{c}\text { WCE } \\
(900-2500)\end{array}$ & & $\begin{array}{c}\text { Field Sur- } \\
\text { vey [32], } \\
\text { DFO KTM } \\
{[34]}\end{array}$ \\
\hline
\end{tabular}

\section{Notes on Species list appendix.}

a) Species name with author citation following http://www.catalogueoflife.org/col/search/all

b) Catalogue of Life: 2018 Annual Checklist (http://www.catalogueoflife.org/annual-checklist/2018/) for nomenclature of angiosperms, gymnosperms and pteridophytes; and mycobank database (mycobank.org) for fungi and lichens. 
c) Life form, Traded part, Occurrence, Global distribution (native range) http://www.plantsoftheworldonline.org/, Distribution in Nepal, Habitat and min-max altitude $(\mathrm{m})$ following Pyakurel et al. 2019.

d) Life form: AH-Annual herb; Epi H-Epiphytic herb; HCL-Herbaceous climber; LT-Large tree; PH-Perennial herb; SH-Shrub; Sp H-Saprophytic herb; SSH-Small shrub; ST-Small tree; T-Tree

e) Occurrence status: Exo_C-Exotic cultivated; Exo_N-Exotic naturalized; Nat_C- native cultivated; Nat_C\&W- native wild and cultivated; Nat_W- native wild

f) Conservation category: CAMP- Conservation Assessment Management Programme (CAMP, 2001); GoN- Government of Nepal (GoN 2001); IUCN- International Union for Conservation of Nature (IUCN, 2020); DD- data deficient; LC- least concern; NT- near threatened; Vuvulnerable; EN- endangered; CR- critically endangered https://www.iucnredlist.org/; Ban Government of Nepal (GoN, 2001) ban on collection, use, transport, trade and export; Ban RE- GoN ban on raw export; Ban FTE- GoN ban on felling, transportation and export; CITES-Convention on International Trade in Endangered Species of Wild Fauna and Flora (CITES, 2020) http://checklist.cites.org/\#/en accessed on 1 June 2020.

\section{References}

1. Spengen $\mathrm{W}$ van (1995) The Geo-History of Long-Distance Trade in Tibet 1850-1950. The Tibet Journal 20(2): 18-63.

2. IFA (Institute of Foreign Affairs) (2013) From a buffer towards a bridge; Nepal's new foreign policy agenda. Ministry of Foreign Affairs, Kathmandu, Nepal.

3. Saxer M (2009) Herbs and Traders in Transit: Border Regimes and the Contemporary Trans-Himalayan Trade in Tibetan Medicinal Plants. Asian Medicine 5: 317-339.

4. Kloos S, Madhavan H, Tidwell T, Blaikie C, Cuomu M (2020) The transnational Sowa Rigpa industry in Asia: New perspectives on an emerging economy. Soc Sci Med 245: 112617.

5. Samuel G (2013) Introduction: Medicine and Healing in Tibetan Societies. East Asian Science, Technology and Society 7(3): 335-351.

6. Saxer M (2013) Manufacturing Tibetan Medicine. The Creation of an Industry and the Moral Economy of Tibetanness. Oxford: Berghahn Books.

7. Dobremez JF (1976) Exploitation and prospects of medicinal plants in eastern Nepal. In: Mountain environment and development, A collection of papers published on the occasion of the 20th anniversary of the Swiss Association for Technical Assistance in Nepal (SATA), Kathmandu: Sahayogi Press, Nepal, pp. 97-107.

8. Hamilton F (1819) An account of the kingdom of Nepal, and of the territories annexed to this dominion by the house of Gorkha. Edinburgh: Archibald Constable and Company.

9. Kirkpatrick W (1811) An account of the kingdom of Nepaul: Being the substance of observations made during a mission to that country in the year 1793. London: WilliamMiller.

10. Olsen CS (2005) Valuation of commercial central Himalayan medicinal plants. Ambio: A Journal of the Human Environment 34(8): 607-610.

11. Ghimire SK, Awasthi B, Rana S, Rana HK, Bhattarai R, et al. (2016) Export of medicinal and aromatic plant materials from Nepal. Botanica Orientalis - Journal of Plant Science 10: 24-32.

12. Chapagain A (2020) Formal Verses Informal Practises: Trade of Medicinal and Aromatic Plants via Trans-Himalayan Silk Road. In: Hung Eva PW, Tak-Wing Ngo (Eds.), Shadow Exchanges along the New Silk Roads, Amsterdam University Press, pp. 145- 161.

13. Pyakurel D, Sharma IB, Smith-Hall C (2018) Pattern of change: The dynamics of medicinal plant trade in far-western Nepal. Journal of ethnopharmacology 224: 323-334.

14. Singh MP, Mallam SB, Rajbhandari SB (1979) Medicinal plants of Nepal - retrospects and prospects. Econ Bot 33: 185-198.

15. Phoboo S, Devkota A, Jha PK (2006) Medicinal Plants in the Nepal An Overview. In: PK Jha et al. (Eds.), Medicinal Plants in Nepal: An
Anthology of Contemporary Research, Kathmandu: Ecological Society, Nepal, pp. 1-24.

16. Jaiswal Y, Liang Z, Zhao Z (2016) Botanical drugs in Ayurveda and traditional Chinese medicine. Journal of Ethnopharmacology 194: 245-259.

17. NPC (National Planning Commission) Nepal (2011) Nepal Status Paper - United Nations Conference on Sustainable Development 2012 (Rio + 20) Synopsis. National Planning Commission, Government of Nepal.

18. MoFE (Ministry of Forests and Environment) (2018) Nepal's sixth national report to the convention on biological diversity. Government of Nepal.

19. Rokaya MB, Münzbergová Z, Shrestha MR, Timsina B (2012) Distribution patterns of medicinal plants along an elevational gradient in central Himalaya, Nepal. Journal of Mountain Science 9: 201-213.

20. Pyakurel D, Smith-Hall C, Sharma IB, Ghimire SK (2019) Trade and conservation of Nepalese medicinal plants, fungi, and lichen. Economic Botany 73: 505-521.

21. Chapagain A, Kafle G, Das AK, Caporale F, Mateo J, et al. (2019) A population list of medicinal plant processing enterprises in Nepal. Department of Food and Resource Economics, University of Copenhagen. IFRO Documentation, No. 2019/3.

22. He J, Yang B, Dong M, Wang Y (2018) Crossing the roof of the world: Trade in medicinal plants from Nepal to China. Journal of Ethnopharmacology 224: 100-110.

23. Pyakurel D, Panthi S (2015) Trade of High Valued MAPs from Nepal to China. Department of Plant Resources, Government of Nepal.

24. PSCN (Practical Solution Consultancy Nepal) (2014) Status Mapping and Trade Analysis of NTFPS/MAPS in Trans-Himalayan Region of Nepal. Department of Plant Resources, Government of Nepal.

25. Schrempf M (2003) Soundings in Tibetan Medicine: Anthropological and Historical Perspectives: Tibetan Studies. Proceedings Tenth Seminar of the International Association for Tibetan Studies, LEIDEN. BOSTON 2007, Brill.

26. Garrett F (2007) Critical methods in Tibetan medical histories. Journal of Asian Studies 66(2): 363-387.

27. Roberti di SP, Luigi O, Joey M (2011) Tibetan medicine: a unique heritage of person-centered medicine. EPMA Journal 2(4): 385-389.

28. Dakpa $T$ (2014) Unique aspect of Tibetan medicine. Acupunct Electrother Res 39(1): 27-43.

29. William M (2017) Buddhism and Medicine in Tibet: Origins, Ethics, and Tradition. PhD Thesis, Religious Studies - Graduate School of Arts and Sciences, University of Virginia.

30. Yang G (2014) The Origin of the Four Tantras and an Account of its Author, Yuthog Yonten Gonpo. In: Hofer T (Ed.), Bodies in Balance - The 
Art of Tibetan Medicine, Rubin Museum of Art, New York in association with University of Washington Press, Seattle and London.

31. Hall CS, Chapagain A, Das AK, Ghimire SK, Pyakurel D, et al. (2020) Trade and conservation of medicinal and aromatic plants - an annotated bibliography for Nepal. Central Department of Botany, Tribhuvan University, Nepal.

32. Field survey (2016) List of medicinal plants exported to China in 2016 via Custom of Tatopani, and Tribhuvan International Airport Field survey among China trading wholesalers at Thamel, Kathmandu [Unpublished].

33. Field survey (2020) Field observation and personal communication with Bhutia traders at Kimathanka-Chentang border crossing point, Sankhuwasabha Field march-April 2020 [Unpublished].

34. DFO KTM (Divisional Forest Office, Kathmandu) (2020) List of Medicinal and Aromatic Plants exported to China [Unpublished]. Divisional Forest Office, Kathmandu.

35. Catalogue of Life (2018) Annual Checklist for nomenclature of angiosperms, gymnosperms and pteridophytes.

36. Plants of the World online (2020, June) Plants of the World online.

37. IUCN (International Union for Conservation of Nature) (2020, June) The IUCN Red List of Threatened Species.

38. CAMP (Conservation Assessment and Management Prioritization) Workshop (2001) Conservation Assessment and Management Prioritization Report. International Development Research Centre (IDRC), Canada and Ministry of Forest and Soil Conservation, Kathmandu, Nepal.

39. Convention on International Trade in Endangered Species of Wild Fauna and Flora (2020, June) CITES Authorities.

40. GoN (Government of Nepal) (2001) Notice of Ministry of Forests and Soil Conservation. Nepal Gazette 51: 36-37.

41. Janes Craig R (1995) The Transformations of Tibetan Medicine. Medical Anthropology Quarterly 9(1): 6-39.

42. Hofer T (2018) Medicine and Memory in Tibet: Amchi Physicians in an Age of Reform. In: Hofer T (Ed.), Reviving Tibetan Medicine, Integrating Biomedicine, University of Washington Press.

43. Rabten $\mathrm{T}$ (2018) The path towards validating Tibetan and Chinese medicine by the food and drug administration. Int J Complement Alt Med 11(6): 317-324.

44. TCT (2019) History of Traditional Tibetan Medicine. Top China Travel (TCT) webpage.

45. Kloos S (2017) The Pharmaceutical Assemblage: Rethinking Sowa Rigpa and the Herbal Pharmaceutical Industry in Asia. Current Anthropology 58(6): 693-717.

46. Natalia B (2019) Mineral raw materials in Tibetan Medicine. Presented at 8th International Conference Buddhism \& Australia 'History, current presence and future directions for Buddhism in Austral-Asian region' 7-9.

47. Pant YP (1962) Nepal-China Trade Relations. The Economic Weekly.

48. Jha HB (2013) Nepal's Border Relations with India and China. Eurasia Border Review 4(1): 63-75.

49. Shrestha BN (2015) Nepal-China Seven border crossing points Nagarik newspaper published on 18 Nov.

50. Amatya OC (2017) Trans-Himalayan Silk Road: An Untold Story. The Himalayan Times (A National Daily Newspaper of Nepal).

51. Pyakurel UP (2017) Nepal-China Border Management and the Future of People to People Relations. Center for Studies on South Asia and the Middle East, National Chung Hsing University, Taiwan.

52. Acharya TP (2000) Conservation of non-timber forest products (NTFPs) in Humla, Nepal: a case study of Rudikot (Margor) region for biodiversity conservation. In: Proceedings of the Third Regional Workshop on Community Based NTFP Management, Kathmandu, Nepal. South and East Asian Countries NTFP Network (SEANN), pp. 264-271.

53. Sherpa S (2001) The High-Altitude Ethnobotany of the Walung People of Walangchung Gola, Kanchenjunga Conservation Area, East Nepal. MSc Thesis, Central Department of Botany, Tribhuvan University.

54. van Boeckel L (2017) MAPs and Essential Oils from Nepal - Market Analysis and Market Entry Strategy in the China Market. Deutsche Gesellschaft für Internationale Zusammenarbeit (GIZ) GmbH.

55. Amatya G (2006) Trade and Socio-Economic Attribution of Cordyceps sinensis (Berk) Saccardo in Darchula District, Nepal. In: Jha PK, Karmacharya SB, Chhetri MK, Thapa CB, Shrestha BB (Eds.), Medicinal Plants in Nepal: An Anthology of Contemporary Research. Ecological Society (ECOS), Nepal, pp. 194-203.

56. Cunningham AB, Brinckmann JA, Schippmann U, Pyakurel D (2018) Production from both wild harvest and cultivation: The cross-border Swertia chirayita (Gentianaceae) trade. Journal of Ethnopharmacology 225: 42-52.

57. Devkota S, Shrestha A (2006) A Study on Ethno-ecology, Regeneration Pattern, Collection Techniques and Trade of Yarsagumba (Cordyceps sinensis): Research in Kangchenjunga Conservation Area and Dolpa Region of Nepal for Policy Recommendations. SAFE Concern and WWF Nepal Program, Kathmandu, Nepal.

58. GoN (Government of Nepal) (2011) A Report on Value Chain Analysis of Timur. High Value Agriculture Project in Hill and Mountain Areas (HVAP). Ministry of Agricultural Development, Project Management Unit, Birendranagar, Surkhet.

59. IFA (Institute of Foreign Affairs) (2015) Promoting Nepalese Trade and Investment Relations with India and China. Ministry of Foreign Affairs, Kathmandu, Nepal.

60. Phoboo S, Jha PK (2010) Trade and Sustainable Conservation of Swertia chirayita (Roxb. ex Fleming) h. Karst in Nepal. Nepal Journal of Science and Technology 11: 125-132.

61. Ghimire SK, Gimenez O, Pradel R, McKey D, Thomas YA (2008) Demographic variation and population viability in a threatened Himalayan medicinal and aromatic herb Nardostachys grandiflora: Matrix modelling of harvesting effects in two contrasting habitats. Journal of Applied Ecology 45(1): 41-51.

62. Cunningham AB (1993) African medicinal plants: Setting priorities at the interface of conservation and primary healthcare, (People and Plants Working Paper 1). UNESCO, Paris.

63. Gaoue OG, Ticktin T (2007) Patterns of harvesting foliage and bark from the multipurpose tree Khaya senegalensis in Benin: Variation across ecological regions and its impacts on population structure. Biological Conservation 137(3): 424-436.

64. Pouliot M, Pyakurel D, Smith Hall C (2018) Pathway out of poverty for upland communities in Nepal high altitude gold and its development potential. Policy Briefs - No. 02. IFRO, University of Copenhagen.

65. IndexMundi (2020, June) China- GDP per capita.

66. Cuomu M (2013) Qualitative Exploration of the Potential Causes of Serious Reduction in Availability of Medicinal Plants in the QinghaiTibetan High Plateau. East Asian Science, Technology and Society: An International Journal 7(3): 397-423. 
67. Caporale F, Mateo Martín J, Usman MF, Smith Hall C (2020) PlantBased Sustainable Development-The Expansion and Anatomy of the Medicinal Plant Secondary Processing Sector in Nepal. Sustainability 12(14): 5575
This work is licensed under Creative Commons Attribution 4.0 License

DOI:10.19080/IJESNR.2021.28.556228
Your next submission with Juniper Publishers will reach you the below assets

- Quality Editorial service

- Swift Peer Review

- Reprints availability

- E-prints Service

- Manuscript Podcast for convenient understanding

- Global attainment for your research

- Manuscript accessibility in different formats

( Pdf, E-pub, Full Text, Audio)

- Unceasing customer service

Track the below URL for one-step submission https://juniperpublishers.com/online-submission.php 